\title{
UJI EFEKTIVITAS JAMBU BIJI MERAH (Psidium guajava) TERHADAP LAJU ALIRAN SALIVA PADA PENDERITA XEROSTOMIA YANG MENGONSUMSI TELMISARTAN
}

\author{
${ }^{1}$ Jemima L. Waworuntu \\ ${ }^{2}$ Jane Wuisan \\ ${ }^{3}$ Christy N. Mintjelungan
}

\author{
${ }^{1}$ Kandidat Skripsi Program Studi Pendidikan Dokter Gigi Fakultas Kedokeran \\ ${ }^{2}$ Bagian Farmakologi Fakultas Kedokteran \\ ${ }^{3}$ Program Studi Kedokteran Gigi Fakultas Kedokteran \\ Universitas Sam Ratulangi \\ Email: liviajemima95@gmail.com
}

\begin{abstract}
A study done by National Center for Biotechnologi Information (NCBI) to the user of antihypertension drugs, $50 \%$ of the individuals are suffering xerosomia or dry mouth. The reduction of saliva because of xerostomia may increase the risk of tooth damage. Vitamin $\mathrm{C}$ contained in red guava (Psidium Guajava) is expected to induce salivary flow rate in Xerostomia patients who consume antihypertensive Telmisartan.The purpose of this study is to acknowledge the effect of red guava in increasing salivary flow rate in Xerosotmia patients who consume antihypertensive Telmisartan. This is a clinical trial study with nonequivalent control group experimental design. Each group has 15 samples from the population of hypertensive patients who consume antihypertensive Telmisartan and are suffering Xerostomia in Pancaran Kasih Hospital and Prof. Dr. RD. Kandou Hospital. The treatment group is given red guava fruit that is already served as pure juice while the control group is only given mineral water. Saliva is collected twice, that is before treatment and after treatment. Saliva is collected by spitting method and the salivary flow rate is measured by using disposable syringe with the measurement of $\mathrm{ml} /$ minute.The result of this study shows that the average of salivary flow rate before of control group is $0.23 \mathrm{ml} /$ minute and the average of salivary flow rate after is $0.28 \mathrm{ml} /$ minute. While the average of salivary flow rate before treatmen in treatment group is $0.24 \mathrm{ml} /$ minute and the average of salivary flow rate after treatment is $0.83 \mathrm{ml} /$ minute. It can be concluded that red guava has been proved to be effectively increase salivary flowrate of xerostomia patients who consume antihypertensive Telmisartan.
\end{abstract}

Keywords: xerostomia, red guava, salivary flow rate

\begin{abstract}
Abstrak: Sebuah studi yang dilakukan oleh National Center for Biotechnology Information (NCBI) yang melakukan penelitian terhadap pengguna obat antihipertensi, sebanyak $50 \%$ menderita Xerostomia atau mulut kering. Laju aliran saliva yang menurun akibat Xerostomia dapat menyebabkan meningkatnya resiko kerusakan gigi. Kandungan vitamin $\mathrm{C}$ pada buah jambu biji merah (Psidium guajava) diharapkan dapat meningkatkan laju aliran saliva pada penderita xerostomia yang mengonsumsi obat antihipertensi golongan Telmisartan.Penelitian ini bertujuan untuk mengetahui efek jambu biji merah dalam meningkatkan laju aliran saliva pada penderita Xerostomia yang mengonsumsi Telmisartan. Penelitian ini adalah penelitian uji klinis dengan rancangan eksperimental nonequivalent control group design. Setiap kelompok beranggotakan 15 orang dari populasi pasien pengguna obat antihipertensi golongan Telmisartan yang menderita Xerostomia di RSU Pancaran Kasih dan RSUP Prof. DR. R. D. Kandou Malalayang. Kelompok perlakuan mengonsumsi buah jambu biji merah yang
\end{abstract}


disajikan dalam bentuk jus murni sedangkan kelompok kontrol hanya mengonsumsi air mineral. Saliva dikumpulkan sebanyak dua kali yaitu sebelum dan sesudah mengonsumsi buah jambu biji merah. Saliva dikumpulkan dengan metode spitting dan laju aliran saliva diukur menggunakan disposable syringe dengan satuan $\mathrm{ml} /$ menit.Hasil penelitian menunjukkan bahwa rerata laju aliran saliva awal pada kelompok kontrol yaitu $0,23 \mathrm{ml} / \mathrm{menit}$ dan laju aliran saliva akhir kelompok kontrol yaitu $0,28 \mathrm{ml} /$ menit. Sedangkan rerata laju aliran saliva awal pada kelompok perlakuan yaitu 0,24 ml/menit dan laju aliran saliva akhir kelompok perlakuan yaitu $0,83 \mathrm{ml} / \mathrm{menit}$. Dapat disimpulkan bahwa buah jambu biji merah dapat meningkatkan laju aliran saliva pada penderita Xerostomia yang mengonsumsi Telmisartan.

Kata kunci: xerostomia, jambu biji merah, laju aliran saliva.

Hipertensi merupakan penyakit yang makin banyak dijumpai di Indonesia, terutama di kota-kota besar. Itu merupakan penyebab utama peningkatan resiko stroke, penyakit arteri koroner dan komplikasinya, serangan jantung, gagal jantung, dan insufisiensi ginjal. ${ }^{1,2}$

Pengobatan hipertensi ditujukan untuk menurunkan tekanan darah, mengurangi dan mencegah komplikasi akibat hipertensi. Obat-obatan yang biasa dipakai untuk pengobatan hipertensi atau dikenal dengan antihipertensi yaitu obat diuretika, penyekat beta, antagonis kalsium, dan penghambat Angiotensin Converting Enzyme (ACE inhibitor). ${ }^{3}$ Salah satu obat antihipertensi yang digunakan ialah golongan telmisartan.

Obat-obatan antihipertensi sering menimbulkan efek samping seperti mual, muntah, diare, sakit kepala, pusing, letih, insomnia, hiperkalemia, dan takikardia, serta sering menimbulkan keluhan mulut kering yang disebut xerostomia. ${ }^{4,5} \mathrm{Obat}$ golongan Telmisartan juga dapat menurunkan laju aliran saliva sehingga jumlah aliran saliva berkurang dan menyebabkan mulut kering atau xerostomia. Penggunaan obat antihipertensi golongan Telmisartan dalam jangka waktu kurang dari 2 minggu sudah dapat menimbulkan xerostomia. ${ }^{6}$

Xerostomia merupakan gejala berupa kekeringan pada mulut akibat jumlah aliran saliva yang berkurang. Keadaan ini dapat meningkatkan kejadian kerusakan gigi. Gejala tersebut dapat terjadi dengan berbagai penyebab, seperti efek samping obat-obatan hipertensi, demam, diare, diabetes, gagal ginjal, berolahraga, stres, bernafas melalui mulut, kelainan saraf, usia, radiasi pada daerah leher dan kepala, dan gangguan lokal pada kelenjar saliva. ${ }^{7}$

Jumlah aliran saliva yang berkurang dapat diatasi dengan berbagai cara, salah satunya yaitu dengan pemberian asam askorbat atau biasa dikenal dengan vitamin C. Vitamin C biasa digunakan untuk mengobati xerostomia. ${ }^{8}$ Menurut penelitian yang dilakukan oleh Bjornstorm dkk., asam askorbat terbukti lebih efektif dibanding saliva buatan. ${ }^{8}$ Vitamin C dapat berupa tablet atau sirup, namun dapat juga ditemukan dalam bermacam-macam sumber makanan seperti paprika, brokoli, kiwi, stroberi, mangga, jeruk, lemon, pepaya, dan jambu biji merah. ${ }^{9}$

Jambu biji merah memiliki rasa yang manis sehingga banyak disukai dan sering diolah menjadi jus. Jambu biji merah memiliki kandungan vitamin $\mathrm{C}$ yang paling tinggi dibandingkan dengan buah-buah yang lain karena per 100 gram jambu biji merah mengandung $228 \mathrm{mg}$ vitamin C. ${ }^{10}$

Berdasarkan hal tersebut, peneliti tertarik untuk melakukan penelitian mengenai efektivitas jambu biji merah terhadap laju aliran saliva pada penderita xerostomia yang mengonsumsi telmisartan.

\section{METODE PENELITIAN}

Jenis penelitian ini merupakan penelitian uji klinis (clinical trial) dengan rancangan eksperimental nonequivalent control group design. Penelitian dilaksanakan di poliklinik penyakit dalam Rumah Sakit Pancaran Kasih dan RSUP Prof. DR. R. D. Kandou Manado,Sulawesi Utara. 
Penelitian dilakukan pada bulan MaretSeptember 2015.Populasi dalam penelitian ini ialah seluruh pasien pengguna obat antihipertensi golongan Telmisartan dengan gejala xerostomia yang ada di Rumah Sakit Pancaran Kasih dan Rumah Sakit Umum Prof. DR. R. D. Kandou Malalayang selama penelitian dimulai sampai selesai dalam kurun waktu yang ditentukan oleh peneliti.Sampel digunakan pada penelitian ini ialah minimal sampel yang layak dalam studi penelitian eksperimen sederhana, yaitu berjumlah 15 orang kelompok perlakuan dan 15 orang kelompok kontrol. ${ }^{11}$ Sampel dalam penelitian ini diambil secara purposive sampling yakni teknik pengambilan sampel berdasarkan pertimbangan peneliti sesuai kriteria inklusi dan eksklusi.

Kriteria inklusi dalam penelitian ini yaitu pasien yang mengonsumsi obatobatan antihipertensi golongan Telmisartan yang menderita Xerostomia, bersedia mengikuti penelitian dengan penandatanganan informed consent, serta pasien umur diatas 20 tahun. Kriteria Eksklusi dalam penelitian ini yaitu pasien yang menjalani terapi radiasi.

Variabel penelitian ini ialah laju aliran saliva pada penderita Xerostomia yang mengonsumsi Telmisartan dan buah jambu biji merah. Laju aliran saliva terstimulasi dengan air mineral pada penderita xerostomia yang mengonsumsi Telmisartan yaitu jumlah aliran saliva subjek penelitian yang akan diukur dengan metode spitting sebelum dan sesudah mengonsumsi jus murni buah jambu biji merah. Laju aliran saliva sebelum mengonsumsi jus murni buah jambu biji merah yaitu kurang atau sama dengan $0,5 \mathrm{ml} / \mathrm{menit}$ dan setelah mengonsumsi jus murni buah jambu biji merah, laju aliran saliva bisa saja menurun $<0,5 \mathrm{ml} /$ menit atau diharapkan meningkat menjadi $>0,5 \mathrm{ml} /$ menit.Buah jambu biji merah yaitu buah yang disajikan dalam bentuk jus murni dengan takaran 100gram dan akan dikonsumsi oleh subjek penelitian untuk diuji efektivitasnya terhadap laju aliran saliva.
Alat yang digunakan dalam penelitian ini yaitu tabung uji untuk menampung saliva, Pisau untuk mengupas dan memotong jambu biji merah, Gelas, Disposable syringe untuk mengukur banyaknya saliva dalam satuan ml,Timer untuk menentukan waktu perlakuan dan pengambilan saliva, Timbangan untuk menimbang takaran jambu biji merah, dan Juicer untuk membuat jus murni dari buah jambu biji merah. Bahan - bahan yang digunakan yaitu buah jambu biji merah, air mineral, tisu, formulir pemeriksaan.

Pengumpulan data untuk kelompok yang mengonsumsi Telmisartan diperoleh dari rekam medik pasien. Pasien yang akan dijadikan sampel diberi informasiawal dan diminta persetujuan untuk ikut menjadi subjek penelitian dengan menyatakan kesediaannya melalui penandatanganan informed consent.

Subjek dibagi menjadi dua kelompok, yaitu kelompok perlakuan jus murni buah jambu biji merah dan kelompok kontrol dengan aquades. Peneliti melakukan pengukuran laju aliran saliva awal dengan mengukur jumlah aliran saliva terstimulasi dengan air mineral menggunakan metode spitting dan hasil dicatat dalam $\mathrm{ml} / \mathrm{menit}$. Subjek diinstruksikan untuk mengakumulasikan saliva didalam mulut tanpa menelan ludah selama 1 menit kemudian meludahkan salivanya ke dalam tabung uji melalui corong. Subjek mengulang prosedur dalam kurun waktu 5 menit. Setelah itu saliva dipindahkan ke disposable syringe kemudian diukur $\mathrm{ml}$ saliva yang terkumpul per satuan menit.Kelompok perlakuan diinstruksikan untuk mengonsumsi 100 gram buah jambu biji merah yang telah dibuat jus murni dan langsung diukur kembali laju aliran saliva dengan metode spitting. Kelompok kontrol diinstruksikan untuk mengonsumsi air mineral dan langsung diukur kembali laju aliran saliva dengan metode spitting.Data diolah dan dianalisis menggunakan program komputer dan disajikan dalam bentuk tabel dan diagram. 


\section{HASIL PENELITIAN}

Berdasarkan hasil penelitian yang dilakukan pada pasien yang mengonsumsi telmisartan di RSU Pancaran Kasih Manado, diperoleh gambaran karakteristik sampel berdasarkan jenis kelamin dan usia (Tabel 1 dan Tabel 2).

Tabel 1 menunjukkan bahwa responden terbanyak menurut jenis kelamin pada kelompok perlakuan ialah responden perempuan (60\%) dan pada kelompok kontrol responden terbanyak juga berjenis kelamin perempuan $(86,7 \%)$.

Tabel 2 menunjukkan bahwapada kelompok perlakuan, respondenterbanyak berusia 51-60 tahun dengan jumlah 8 orang (53,4\%). Pada kelompok kontrol, responden terbanyak berusia 41-50 tahun dengan jumlah 5 (33,3\%).

Tabel 1. Distribusi karakteristik responden menurut jenis kelamin

\begin{tabular}{ccccc}
\hline & \multicolumn{2}{c}{ Kelompok perlakuan } & \multicolumn{2}{c}{ Kelompok kontrol } \\
\hline Jenis kelamin & $\mathrm{n}$ & $\%$ & $\mathrm{n}$ & $\%$ \\
Perempuan & 9 & 60 & 13 & 86,7 \\
Laki-laki & 6 & 40 & 2 & 13,3 \\
Jumlah & 15 & 100 & 15 & 100 \\
& & & & \\
\hline
\end{tabular}

Tabel 2. Distribusi karakteristik responden menurut usia

\begin{tabular}{ccccc}
\hline & \multicolumn{2}{c}{ Kelompok perlakuan } & \multicolumn{2}{c}{ Kelompok kontrol } \\
\hline Usia (Tahun) & $\mathrm{n}$ & $\%$ & $\mathrm{n}$ & $\%$ \\
\hline $30-40$ & 3 & 20 & 1 & 6,7 \\
$41-50$ & 4 & 26,6 & 5 & 33,3 \\
$51-60$ & 8 & 53,4 & 9 & 60 \\
\hline Jumlah & 15 & 100 & 15 & 100 \\
\hline
\end{tabular}

Uji normalitas dilakukan menggunakan teknik Kolmogorov-Smirnov. Kriteria pengujian normalitas yaitu data berdistribusi normal bila nilai signifikansi $>0,05 .{ }^{12}$ Perhitungan lengkap dapat dilihat dalam lampiran 4. Nilai signifikansi laju aliran saliva awal kelompok perlakuan, laju aliran saliva akhir kelompok perlakuan, laju aliran saliva awal kelompok kontrol, dan laku aliran saliva akhir kelompok kontrol ialah >0,05. Maka dapat disimpulkan bahwa semua kelompok data berdistribusi normal.

Uji homogenitas dilakukan menggunakan uji Fmax dengan cara menghitung nilai varians. $^{12}$ Kelompok data yang diuji homogenitasnya adalah antara data laju aliran saliva awal kelompok perlakuan $\left(\mathrm{O}_{1}\right)$ dan laju aliran saliva awal kelompok kontrol $\left(\mathrm{O}_{3}\right)$; juga antara data laju aliran saliva akhir kelompok perlakuan $\left(\mathrm{O}_{2}\right)$ dan laju aliran saliva akhir kelompok kontrol $\left(\mathrm{O}_{4}\right)$. Kriteria pengujian yaitu kedua kelompok data homogen bila $\mathrm{F}$ hitung $<\mathrm{F}$ tabel pada taraf kesalahan tertentu. ${ }^{12}$ Bila ditetapkan taraf kesalahan 0,5\% maka $\mathrm{F}$ tabel adalah 3,74.

Pasangan kelompok data $\mathrm{O}_{1}$ dan $\mathrm{O}_{3}$ memiliki nilai $\mathrm{F}$ hitung 1 , dan pasangan kelompok data $\mathrm{O}_{2}$ dan $\mathrm{O}_{4}$ memiliki nilai $\mathrm{F}$ hitung 1,5. Dengan demikian, setiap pasangan kelompok data memliki $\mathrm{F}$ hitung < F tabel. Maka dapat disimpulkan bahwa setiap pasangan kelompok data homogen. Tabel perhitungan lengkap dapat dilihat pada lampiran 4.

Efektivitas jambu biji merah terhadap laju aliran saliva pada penderita xerostomia yang mengonsumsi Telmisartan diuji menggunakan paired sample t-test dengan membandingkan data antara laju aliran saliva awal kelompok perlakuan $\left(\mathrm{O}_{1}\right)$ dan 
laju aliran saliva awal kelompok kontrol $\left(\mathrm{O}_{3)}\right.$ sertalaju aliran saliva akhir kelompok perlakuan $\left(\mathrm{O}_{2}\right)$ dan laju aliran saliva akhir kelompok kontrol $\left(\mathrm{O}_{4}\right)$. Kriteria pengujian yaitu apabila t hitung $<\mathrm{t}$ tabel, $\mathrm{p}>0,05$, maka ditentukan bahwa tidak ada perbedaan antara rata-rata jumlah aliran saliva pada setiap pasangan kelompok data. Sebaliknya, apabila t hitung $>\mathrm{t}$ tabel, $\mathrm{p}<$ 0,05, maka ditentukan bahwa ada perbedaan antara rata-rata jumlah aliran saliva pada setiap pasangan kelompok data. $^{12}$

Tabel distribusi $\mathrm{t}$ dicari pada taraf kesalahan 5\% : $2=2,5 \%$ (uji 2 sisi) dengan derajat kebebasan n-1 atau 15-1 = 14. Tabel 3 menunjukkan bahwa dengan pengujian 2 sisi (signifikansi $=0,25$ ) maka hasil diperoleh untuk t tabel yaitu 2,14.

Berdasarkan Tabel 4 dapat dilihat bahwa pasangan kelompok data $\mathrm{O}_{1}$ dan $\mathrm{O}_{3}$ memiliki nilai $\mathrm{t}$ hitung $<\mathrm{t}$ tabel dengan nilai p 0,161 atau > 0,05. Maka dapat disimpulkan bahwa tidak ada perbedaan antara laju aliran saliva awal pada kelompok perlakuan dan kelompok kontrol. Hal ini menunjukkan bahwa sampel kelompok perlakuan $\left(\mathrm{O}_{1}\right)$ dan kelompok kontrol $\left(\mathrm{O}_{2}\right)$ memiliki keadaan awal yang sama.

Tabel 3. Uji paired sample t-test

\begin{tabular}{cccc}
\hline $\begin{array}{c}\text { Pasangan kelompok } \\
\text { data }\end{array}$ & t hitung & t tabel & $\mathrm{P}$ \\
\hline $\mathrm{O}_{1}$ dan $\mathrm{O}_{3}$ & 1,48 & 2,14 & $>0,05$ \\
$\mathrm{O}_{2}$ dan $\mathrm{O}_{4}$ & 12,18 & 2,14 & $<0,05$ \\
\hline
\end{tabular}

Tabel 4. Rerata laju aliran saliva pada kelompok perlakuan dan kelompok kontrol

\begin{tabular}{cccc}
\hline \multicolumn{4}{c}{ Laju aliran saliva } \\
\hline Kelompok & Sebelum & Sesudah & Selisih \\
\hline Perlakuan & 0,24 & 0,83 & 0,59 \\
Kontrol & 0,23 & 0,28 & 0,05 \\
\hline
\end{tabular}

Pasangan kelompok data $\mathrm{O}_{2}$ dan $\mathrm{O}_{4}$ memiliki nilai $\mathrm{t}$ hitung $>\mathrm{t}$ tabel dengan nilai p 0,00 atau $<0,05$. Maka dapat disimpulkan bahwa terdapat perbedaan yang bermakna antara laju aliran saliva awal pada kelompok perlakuan dan kelompok kontrol. Karena rerata $\mathrm{O}_{2}>$ rerata $\mathrm{O}_{4}$ (tabel 3) maka laju aliran saliva kelompok perlakukan lebih besar dari pada kelompok kontrol. Ini menunjukkan adanya pengaruh perlakuan jus jambu biji merah terhadap laju aliran saliva.

Rerata laju aliran saliva sebelum mengonsumsi jus jambu biji merah pada kelompok perlakuan ialah $0,24 \mathrm{ml} /$ menit, dan setelah mengonsumsi jus jambu biji merah rerata laju aliran saliva ialah 0,83 $\mathrm{ml} /$ menit. Laju aliran saliva sebelum dan sesudah mengonsumsi jus jambu biji merah pada kelompok perlakuan memiliki selisih $0,59 \mathrm{ml} / \mathrm{menit}$. Rerata laju aliran saliva awal kelompok kontrol adalah 0,23 $\mathrm{ml} / \mathrm{menit}$ dan laju aliran saliva akhir adalah $0,28 \mathrm{ml} /$ menit. Laju aliran saliva awal dan akhir pada kelompok kontrol memiliki selisih 0,05 ml/menit (dapat dilihat pada Tabel 4).

Rerata laju aliran saliva pada kelompok perlakuan jus jambu biji merah dan kelompok kontrol digambarkan dalam grafik sebagai berikut. (Gambar 4).

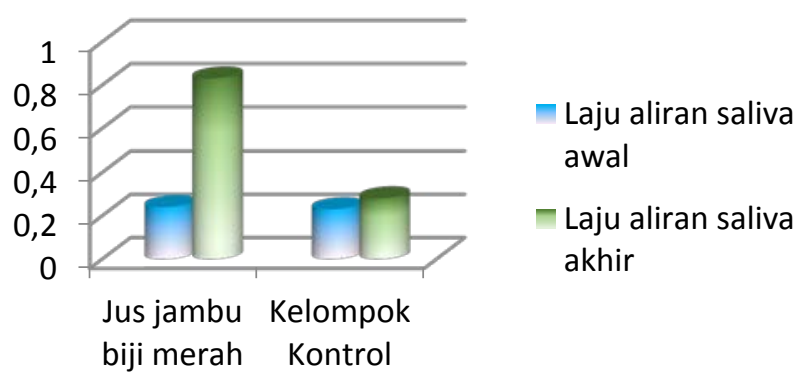

Gambar 4. Diagram rerata laju aliran saliva 
Diagram rerata laju aliran saliva di atas dapat dilihat perbedaan yang jelas dari dua kelompok. Pada kelompok kontrol tidak terjadi peningkatan laju aliran saliva yang bermakna yaitu dari $0,23 \mathrm{ml} /$ menit menjadi $0,28 \mathrm{ml} /$ menit. Sedangkan pada kelompok perlakuan yang diberikan jus jambu biji merah terjadi peningkatan laju aliran saliva yang sangat signifikan yaitu dari 0,24 $\mathrm{ml} /$ menit menjadi $0,83 \mathrm{ml} / \mathrm{menit}$.

\section{BAHASAN}

Obat antihipertensi termasuk Telmisartan dapat memengaruhi laju aliran saliva. Obat ini dapat mempengaruhi aliran saliva secara langsung dan tidak langsung. Bila secara langsung akan mempengaruhi aliran saliva dengan meniru aksi sistem syaraf autonom atau dengan bereaksi pada proses seluler yang diperlukan untuk saliva. Stimulasi saraf parasimpatis menyebabkan sekresi yang lebih cair dan saraf simpatis memproduksi saliva yang lebih sedikit dan kental. Sedangkan secara tidak langsung akan mempengaruhi saliva dengan mengubah keseimbangan cairan dan elektrolit atau dengan mempengaruhi aliran darah ke kelenjar. ${ }^{13}$

Jambu biji merah merupakan sumber vitamin $\mathrm{C}$ alamiah yang memiliki kadar vitamin $C$ sangat tinggi dibandingkan buahbuah yang lain seperti jeruk atau pepaya. Kandungan tertinggi yang terdapat dalam buah jambu biji merah adalah vitamin $\mathrm{C}$ dengan takaran $228 \mathrm{mg}$ per 100 gram buah jambu biji merah.

Penelitian mengenai efek vitamin C terhadap peningkatan laju aliran saliva telah banyak dilakukan namun menggunakan perlakuan melalui suplemen. Penelitian oleh Bjornstorm tentang vitamin $\mathrm{C}$ juga pernah dilakukan yaitu membandingkan peningkatan laju aliran saliva antara mengonsumsi vitamin $\mathrm{C}$ dan memakai saliva buatan. Penelitian ini membuktikan bahwa vitamin $\mathrm{C}$ lebih efektif dibandingkan saliva buatan sehingga biasa digunakan untuk mengobati xerostomia.

Penelitian ini dilakukan pada 30 orang responden mengonsumsi Telmisartan.
Semua responden menderita Xerostomia berdasarkan pengukuran laju aliran saliva. Dalam penelitian ini distribusi responden berdasarkan jenis kelamin penderita Xerostomia yang mengonsumsi Telmisartan terbanyak yaitu perempuan dengan jumlah 9 orang pada kelompok perlakuan dan 13 orang pada kelompok kontrol. Sedangkan distribusi responden berdasarkan usia terbanyak pada umur 51 kontrol. Sedangkan distribusi responden berdasarkan usia terbanyak pada umur 51 sampai 60 tahun yaitu berjumlah 8 orang pada kelompok perlakuan dan 9 orang pada kelompok kontrol.

Pada penelitian, pertama kali diukur laju aliran saliva awal dari penderita Xerostomia yang mengonsumsi Telmisartan baik pada kelompok perlakuan maupun kelompok kontrol. Setelah dilakukan pengukuran saliva awal, kelompok perlakuan mengonsumsi jus jambu biji merah sedangkan kelompok kontrol mengonsumsi aquades. Setelah itu dilakukan pengukuran kembali laju aliran saliva akhir dari kedua kelompok.

Data hasil penelitian dianalisis menggunakan program komputer dengan membandingkan laju aliran saliva awal penderita Xerostomia yang mengonsumsi Telmisartan pada kelompok perlakuan dan kelompok kontrol. Hal ini dilakukan untuk melihat keadaan awal dari kedua kelompok. Analisis penelitian menunjukkan tidak adanya perbedaan antara $\mathrm{O}_{1}$ (laju aliran saliva awal kelompok perlakuan) dan $\mathrm{O}_{3}$ (laju aliran saliva awal kelompok kontrol) yaitu $\mathrm{t}$ hitung $<\mathrm{t}$ tabel dan p 0,161 atau $>$ 0,05 . Tidak adanya perbedaan antara $\mathrm{O}_{1}$ dan $\mathrm{O}_{3}$ tersebut menunjukkan bahwa sebelum kelompok perlakuan dan kelompok kontrol diberikan apapun keadaan awal yang dimiliki sama.

Analisis penelitian dilakukan dengan membandingkan laju aliran saliva akhir penderita Xerostomia yang mengonsumsi Telmisartan pada kelompok perlakuan dan kelompok kontrol. Analisis penelitian menunjukkan adanya perbedaan yang sangat signifikan antara $\mathrm{O}_{2}$ (laju aliran 
saliva akhir kelompok perlakuan) dan $\mathrm{O}_{4}$ (laju aliran saliva akhir kelompok kontrol) yaitu t hitung $>$ t tabel dan p 0,00 atau $<$ 0,05 .

Rerata laju aliran saliva awal kelompok kontrol adalah 0,23 ml/menit. Hal ini sesuai dengan indikator laju aliran saliva yang tidak normal pada penderita Xerostomia yaitu kurang dari $0,5 \mathrm{ml} /$ menit. Laju aliran saliva akhir kelompok kontrol adalah 0,28 $\mathrm{ml} / \mathrm{menit}$. Dapat dilihat bahwa laju aliran saliva akhir kelompok kontrol masih tetap tergolong tidak normal.

Rerata laju aliran saliva responden pada kelompok perlakuan sebelum diberikan jus jambu biji merah adalah $0,24 \mathrm{ml} /$ menit. Rerata laju aliran saliva responden setelah diberikan jus jambu biji merah adalah 0,83 $\mathrm{ml} /$ menit. Dapat dilihat bahwa setelah mengonsumsi jus jambu biji merah, laju aliran saliva responden sangat meningkat bahkan menjadi lebih dari $0,5 \mathrm{ml} /$ menit.

Dengan demikian dapat disimpulkan bahwa jambu biji merah efektif terhadap laju aliran saliva pada penderita Xerostomia yang mengonsumsi Telmisartan. Oleh karena vitamin C merupakan kandungan tertinggi yang dimiliki oleh buah jambu biji merah, juga jambu biji merah tergolong buah yang mengandung vitamin $\mathrm{C}$ terbanyak dibanding dengan buah-buahan yang lain, maka diduga bahwa peningkatan laju aliran saliva pada penderita Xerostomia yang mengonsumsi Telmisartan disebabkan oleh vitamin $\mathrm{C}$ dari jus jambu biji merah yang dikonsumsi oleh responden pada kelompok perlakuan.

\section{SIMPULAN}

Dari hasil penelitian dapat disimpulkan bahwa jambu biji merah efektif terhadap laju aliran saliva penderita xerosomia yang mengonsumsi telmisartan.

\section{SARAN}

1. Jus jambu biji merah disarankan agar menjadi alternatif untuk meningkatkan laju aliran saliva penderita Xerostomia yang mengonsumsi Telmisartan.

2. Disarankan untuk dilakukan penelitian lanjutan tentang rentang waktu efektivitas jambu biji merah atau membandingkan efektivitas jambu biji merah dengan sumber vitamin $\mathrm{C}$ yang lain.

3. Disarankan untuk dilakukan penelitian lanjutan dengan kontrol yang berbeda untuk lebih meniliti pengaruh vitamin $\mathrm{C}$ yang dikandung oleh buah jambu biji merah terhadap peningkatan laju aliran saliva.

\section{DAFTAR PUSTAKA}

1. Tambayong J. Patofisiologi untuk keperawatan. Jakarta: EGC, 2000; p. 94.

2. Laurence B, Donald B, Iain B, Keith $\mathbf{P}$. Goodman and Gilman manual farmakologi dan terapi. Jakarta: EGC, 2008; p. 507.

3. Gunawan L. Hipertensi: Tekanan darah tinggi. Yogyakarta: Penerbit Kanisius, 2007, p. 28.

4. Offermanns, Rosenthal E. Encyclopedia of molecular pharmacology. 2nd Edition. Berlin: Springer, 2008; p. 142.

5. Fox PC. Xerostomia. Supplement to access. America: ADH association, 2008; 1-3.

6. Nonzee V. Xerostomia, hypo salivation and oral microbiota in patients using antihypertensive medications. Thailand; National Center for Biotechnology Information, 2010; 95(1): 96-104.

7. Guggenheimer. Xerostomia: Etiology, recognition and treatment. J Am Dental Association. 2003;134(1):61-9.

8. Bjornstorm $M$, Axel $T$, Birkhed $D$. Comparison between saliva stimultants and saliva substitutes in patients with symptoms related to dry mouth. In: Visvanathan V, Nix P. Managing the patient presenting with xerostomia. Int J Clin Pract. 2010; 64(3): 404-407.

9. Stegeman C. A, Davs J. R. The Dental Hygienist's Guide To Nutritional Care. Edisi 3. Canada: Elsevier Inc., 2010; p.140.

10.Soedjito. Budi Daya Jambu biji merah. Yogyakarta: Kanisius, 2012; p. 10

11.Frankel JP, Wallen NE. How to design and 
Waworuntu, Wuisan, Mintjelungan: Uji efektivitas jambu...

evaluate research in education. New York: McGraw-Hill Companies, Inc., 2008: p. 92.

12.Priyanto D. Paham analisa statistik data dengan SPSS. Yogyakarta:
MediaKom, 2010: p. 11-37.

13.Hadyanto L. Farmakologi Kardiovaskuler. Edisi 2. Jakarta: Sofmedia,2009; p. 613. 